\title{
Hepatocyte Growth Factor-Like Protein
}

National Cancer Institute

\section{Source}

National Cancer Institute. Hepatocyte Growth Factor-Like Protein. NCI Thesaurus. Code C131153.

Hepatocyte growth factor-like protein $(711 \mathrm{aa}, \sim 80 \mathrm{kDa}$ ) is encoded by the human MST 1 gene. This protein plays a role in the positive regulation of both macrophage activation and ciliary motility. 